\title{
ISTA RULES CHANGES IN SEED GERMINATION TESTING AT THE BEGINNING OF THE $21^{\text {ST }}$ CENTURY IZMENE ISTA PRAVILA ZA ISPITIVANJE KLIJAVOSTI SEMENA NA POČETKU 21. VEKA
}

\author{
Marija MILIVOJEVIĆ ${ }^{*}$ Zita RIPKA**, Tanja PETROVIĆ \\ *Maize Research Institute Zemun Polje, Slobodana Bajića 1, 11185, Zemun, Belgrade, Serbia \\ ${ }^{* * *}$ National Food Chain Safety Office, Keleti Károly u. 24, 1024 Budapest. Hungary \\ e-mail:mmarija@mrizp.rs
}

\begin{abstract}
The International Seed Testing Association (ISTA) was established in 1924 with the idea of standardization in seed testing worldwide. The first international rules for seed testing (ISTA Rules) were published in 1931. The development of ISTA Rules is constant. ISTA members are involved in the ongoing process of developing methods for seed sampling and testing. The methods are validated to ensure that test procedures provide reliable and reproducible results. Since 2001, ISTA Rules have been issued annually. ISTA accredited laboratories have to work according to valid ISTA Rules. In this paper, ISTA Rules changes in seed germination testing since 2001 were presented. Changes in testing methods, criteria for seedling evaluation, procedure of calculation and reporting of results are presented in detail. It can be concluded that the amendments to the ISTA Rules are necessary in order to harmonize seed testing and modern trends in seed trade.
\end{abstract}

Key words: ISTA Rules, seed, germination.

\section{REZIME}

Međunarodna organizacija za ispitivanje semena (ISTA) je osnovana 1924. godine sa idejom ujednačavanja procesa ispitivanja semena širom sveta. Prva međunarodna pravila za ispitivanje semena (ISTA Pravila) su objavljena 1931. godine. Razvoj ISTA Pravila je konstantan. ISTA članice su uključene u stalan proces razvoja metoda za uzorkovanje i ispitivanje semena. Metode prolaze kroz odgovarajuće ispitivanje validnosti kako bi se obezbedilo da procedure testova daju pouzdane i ponovljive rezultate. Od 2001. godine izdaju se nova ISTA Pravila svake godine. ISTA akreditovane laboratorije imaju obavezu da svoj sistem kvaliteta i svoj rad usaglase sa važećim ISTA Pravilima. U ovom radu prikazane su izmene ISTA Pravila u oblasti ispitivanja klijavosti semena od 2001. godine kao najvažnijeg parametra kvaliteta za promet semena. Pregled izmena ISTA Pravila je sproveden korišćenjem štampanih $i$ elektronskih izdanja. U analizi su takođe korišćeni dokumenti sa ISTA godišnjih sastanaka u kojima su data objašnjenja za predložene izmene. Analizom je ustanovljeno da su u prethodnih 18 godina uvedene brojne izmene u ISTA Pravila za oblast ispitivanja klijavosti. Metode klijavosti za trinaest novih vrsta je uvedeno u Pravila, nekoliko metoda je izmenjeno, dozvoljena je upotreba novih substrata za naklijavanje kao i kombinacija substrata. Novi tipovi nenormalnosti su dodati $i$ za određene vrste su izmenjeni kriterijumi za ocenu klijavosti. Za veliki broj pravila su data dodatna objašnjenja. Najvažnije izmene pravila su doprinele da proces ispitivanja klijavosti semena postane brži $i$ jednostavniji što je neophodno radi usklađivanja načina ispitivanja $i$ savremenih tokova u prometu semena.

Ključne reči: ISTA Pravila, seme, klijavost.

\section{INTRODUCTION}

The International Seed Testing Association (ISTA) was established in 1924 with the idea of uniformity in seed testing worldwide. ISTA's main goal is development of standard procedures for sampling and seed testing which are published in the International Seed Testing Rules (ISTA Rules). Before being accepted into the ISTA Rules, most test methods have gone through collaborative study among laboratories to ensure that the test procedure gives reliable and reproducible results. Method standardization, also known as validation was developed at the end of $19^{\text {th }}$ century (Steiner et al., 2008), but this system was not consistent until the end of the $20^{\text {th }}$ century when method validation procedure for seed testing was established. ISTA members are involved in the ongoing process of developing methods for seed sampling and testing. Proposals of Rules changes are most often originated from technical committees and must be supported by a reviewed validation report. After approval by ISTA Executive Committee, ISTA members vote and finally accept or reject a proposal at ISTA Annual Meetings.

Seed testing has a long tradition (Muschick, 2010). The first ISTA Rules were published in 1931. Ever since the content and format of the ISTA Rules have been changing at intervals. Some changes were minor (editorial changes and corrections), but some were very important (changes in test methods and the introduction of new methods). At the beginning of the $21^{\text {st }}$ century format changes of ISTA Rules were initiated (Jones and Kahlert, 2005). The process of amalgamation of Rules and Annexes started in 2004 with Chapter 2 (Sampling), and finished with germination chapter in 2008. Important milestones in the area of germination were reported by Klitgård, (2002). Annual editions of the ISTA Rules were introduced in 2001 (Jones and Allen, 2017) first as exchange pages and since 2015 electronic version of the actual year is available. Every year, ISTA accredited laboratories have to update their technical knowledge and practice according to the valid ISTA Rules which is checked by Proficiency tests (Milivojević et al., 2008; Kojić et al., 2011; 2016). In such a way analysts in the laboratory deal with the current versions. Previous changes in Rules are being suppressed and the year of introduction into Rules is very often forgotten. Therefore, an overview of the most important changes is very useful. In this paper ISTA Rules changes in seed germination testing since 2001 are presented . The detailed survey of ISTA Rules changes since 2001 using hard copies as well as electronic issues was performed. At the same time, documents "Rules Proposals for the International Rules for Seed Testing" on ISTA web site (www.seedtest.org ) with explanations regarding proposed changes were followed. 


\section{IMPORTANCE OF GERMINATION TEST}

High quality seed is the key factor in commercial seed production (Sečanski et al., 2015). Although seed vigour is very important parameter of seed quality (Milivojević, 2016; Milivojević et al., 2017), germination of a seed lot is essential for seed trade (Vujaković et al., 2011). Therefore germination testing has been part of the ISTA Rules from the very beginning. Already in the first ISTA Rules (1931) germination testing was addressed as a separate chapter (first Chapter 4, since 1959 Chapter 5). In this chapter definitions and instructions for each step in the germination testing are given (growing media, material and apparatus, test procedure, retesting, calculation and expression of results, reporting results, and germination methods in Table 5A). Over time, ISTA Rules changed both content and form according to the voting at the Annual ISTA Meetings (Table 1). Amendments from 2002 regarding germination testing were given in Table 2, and most of them were discussed in the following paragraphs.

Table 1: Year and location of ISTA Meetings where ISTA Rules were adopted

\begin{tabular}{|c|c|}
\hline Year & Location of ISTA Meeting \\
\hline 2001 & Angers, France \\
\hline 2002 & Santa Cruz, Bolivia \\
\hline 2003 & Zurich, Switzerland \\
\hline 2004 & Budapest, Hungary \\
\hline 2005 & Bangkok, Thailand \\
\hline 2006 & Zurich, Switzerland \\
\hline 2007 & Iguacu Falls, Brazil \\
\hline 2008 & Bologna, Italy \\
\hline 2009 & Zurich, Switzerland \\
\hline 2010 & Cologne, Germany \\
\hline 2011 & Zurich, Switzerland \\
\hline 2012 & Venlo, Netherlands \\
\hline 2013 & Antalya, Turkey \\
\hline 2014 & Edinburgh, United Kingdom \\
\hline 2015 & Montevideo, Uruguay \\
\hline 2016 & Tallin, Estonia \\
\hline 2017 & Denver, SAD \\
\hline
\end{tabular}

\section{ADDITION OF NEW SPECIES}

In ISTA Rules (2018) testing methods for 326 agricultural and vegetable, 192 tree and shrub and 351 flower, spice, herb and medicinal species are given. In total, 869 species are covered by the Rules at the moment. Compared to ISTA Rules (1953) with 183 species, it is almost 700 new plant species added. This number is an indicator of tremendous effort of Germination Committee members. In the $21^{\text {st }}$ century 13 new species were introduced into Rules (table 1), while three species were deleted in 2004 (Andropogon scoparius, Brassica pervidis, Medicago tornata). In 2012 new germination method for Solanum nigrum was added.

\section{AMENDMENTS TO TEST METHODS}

Right choice of seed testing method is crucial in order to obtain adequate estimation of seed lot quality. Use of different substrate may lead to discrepancy between testing results. Germination testing in sand of maize landraces accessions from gene bank gave better results with higher correlation with field emergence than filter paper method (Babić et al., 2015). Filter paper, sand and soil were allowed substrates for germination testing until 2002, when compost was added in the ISTA Rules. In 2006 term "substrate" was replaced by "growing media" and "compost" by "organic growing media". At that time organic growing media was only allowed for germination testing of
Helianthus annuus, but afterwards it was added for Vicia faba (2010). Comparative study showed that repeatability and reproducibility is higher with organic growing media than with the other media sand and between paper (Ducournau et al., 2010). Results of normal seedlings also increased with the use of organic growing media compared to the two other substrates.

Each substrate mentioned can be used in several ways. For example, seed can be placed on top of filter paper (TP) or between filter paper (BP). ISTA Rules (Table 5A) indicate the prescribed substrates, temperatures and test durations, recommended procedures for breaking dormancy, additional directions and additional advice. Top of paper covered with sand (TPS) was added to methods in order to overcome germination media disparity between the ISTA (ISTA Rules, 2009) and AOSA (Association of Official Seed Analysts) Rules (2006). In 2009, TPS was added to Pisum, and the year after to Glycine max, Helianthus annuus, Phaseolus vulgaris and Zea mays. A key advantage of this medium is the uniformity in sand based tests allowed by use of dry sand and calibrated moisture application through sprayer tables (Fiedler et al., 2010).

In 2010 BP method was added for Brassica spp. and Sinapis alba since statistical evaluation of the germination test results in validation study showed no significant difference between BP and TP method (Ripka, 2010). Using the TP substrate prescribed in the ISTA Rules (ISTA, 2008) was inefficient when testing large numbers of samples in terms of the space required in the germination facilities. Very common in plant world is presence of seed dormancy which can be classified as physiological, morphological, morphophysiological, physical and combinational (Baskin and Baskin, 2014). ISTA Rules prescribe different procedures for promoting germination of dormant seed (prechilling, preheating, light, $\mathrm{KNO}_{3}, \mathrm{GA}_{3}$ etc.). When duration of prechilling is estimated, post harvest maturation has to be taken into account which depends on a variety, geographical origin, seed colour, storage conditions etc. (Vujinović et al., 2006; Ristić et al., 2013). For certain species light is necessary for promoting germination. In such cases germination test samples are illuminated at least for $8 \mathrm{~h}$ in every $24 \mathrm{~h}$ cycle and during the high temperature period. Hilhorst and Karssen (1989) proved that red light and addition of nitrate to the germination medium induced germination of dormant Sisymbrium officinale seeds. In 2003, ISTA validation study showed that light is necessary for germination seed of Impatiens walleriana. Also $\mathrm{KNO}_{3}$ was added for breaking dormancy in Hordeum vulgare (ISTA, 2007) and Brassica napus (ISTA, 2008). Validation study confirmed that $\mathrm{KNO}_{3}$ alone or in combination with heat is preferable method for breaking dormancy of Brachiaria brizantha seeds (Aranciaga, 2010), the new species introduced into ISTA Rules in 2010. New instructions for germination testing of tree and shrub species regarding prechilling period (28 days for Pinus ponderosa) and prechilling temperature $\left(3-5^{\circ} \mathrm{C}\right.$ for Pinus densiflora) were given (ISTA Rules, 2005). The same year text changed for additional directions for Eucalyptus spp. as a guideline for using weighted replicates method described in Chapter 13. In 2007 for Betula pendula and B. pubescens germination by counted ( 4 x 100 seeds) replicates as well as by weighed replicate was allowed.

\section{EVALUATION OF SEEDLINGS}

Seed quality depends on many factors: environmental conditions, moment of harvest, seed processing, seed storage etc. (Milošević and Ćirović, 1994). Seed reaches maximum germination and vigour at the moment of physiological maturity (Copeland and McDonald, 2001; TeKrony and Hunter, 1995). During harvest and seed processing different mechanical damage can occur influencing higher percentage of abnormal seedlings 
Table 2: ISTA Rules changes in Chapter 5 Germination since 2002

\begin{tabular}{|c|c|c|c|c|c|c|}
\hline $\begin{array}{l}\text { ISTA } \\
\text { Rules }\end{array}$ & New species & $\begin{array}{c}\text { Amendments to test } \\
\text { methods }\end{array}$ & Evaluation of seedlings & Improvements & $\begin{array}{c}\text { Calculation \& } \\
\text { Reporting results }\end{array}$ & Clarifications \\
\hline 2002 & $\begin{array}{l}\text { Solanum } \\
\text { tuberosum }\end{array}$ & compost introduced & $\begin{array}{l}\text { maize with coleoptile } \\
\text { and } 1^{\circ} \text { leaf defects }\end{array}$ & $\begin{array}{l}\text { pure seeds from the } \\
\text { submitted sample } \\
\text { paralel testing } \\
\text { pH out of } 6.0-7.5\end{array}$ & $\begin{array}{l}\text { zero must be } \\
\text { reported as „,0“ } \\
\text { rounding results } \\
\text { amended }\end{array}$ & \\
\hline 2003 & $\begin{array}{l}\text { Crotalaria } \\
\text { brevidens, Poa } \\
\text { secunda }\end{array}$ & $\begin{array}{l}\text { light for Impatiens } \\
\text { walleriana }\end{array}$ & & & & \\
\hline 2004 & \begin{tabular}{|c|} 
Elymus \\
lanceolatus \\
Medicago \\
littoralis Achillea \\
clavennae
\end{tabular} & & & & & \\
\hline 2005 & Pinus brutia & $\begin{array}{c}\text { additional directions } \\
\text { for Pinus }\end{array}$ & & & & double test \\
\hline 2006 & & $\begin{array}{l}\text { organic growing } \\
\text { media }(\mathrm{O})\end{array}$ & & & $\begin{array}{c}\text { fresh seeds } \\
\text { tolerances at least } \\
\text { for normal seedlings } \\
\end{array}$ & \\
\hline 2007 & \begin{tabular}{|c|} 
Triticum \\
dicoccum; Avena \\
nuda; Crambe \\
abyssinica \\
\end{tabular} & $\begin{array}{c}\mathrm{KNO}_{3} \text { for } \\
\text { Hordeum vulgare }\end{array}$ & & & & \\
\hline 2008 & & $\begin{array}{c}\mathrm{KNO}_{3} \text { for } \\
\text { Brassica napus }\end{array}$ & $\begin{array}{l}\text { Harmozation with } \\
\text { Handbook }\end{array}$ & & & \\
\hline 2009 & & TPS for Pisum & $\begin{array}{c}\text { Harmozation with } \\
\text { Handbook }\end{array}$ & & & \\
\hline 2010 & $\begin{array}{l}\text { Brachiaria } \\
\text { brizantha }\end{array}$ & $\begin{array}{l}\text { BP for Brassica \& } \\
\text { Sinapis alba; } \\
\text { TPS for Glycine, } \\
\text { Helianthus, } \\
\text { Phaseolus, Zea; } \\
\text { O for Vicia faba }\end{array}$ & & & & \\
\hline 2011 & & & \begin{tabular}{|c|}
$50 \%$ rule added \\
slight defects: $>3$ cotiledons or \\
$1^{\circ}$ leaves; fused cotiledons \\
abnormalities: seedling \\
unbalanced; detached \\
endosperm ; negative \\
phototropism; cotyledons \\
fused on both sides
\end{tabular} & $\begin{array}{l}\text { biological tests can } \\
\text { replace } \mathrm{pH} \text { \& } \\
\text { conductivity; } \\
\text { testing fewer than } 400 \\
\text { seeds }\end{array}$ & $\begin{array}{l}\text { all pre-treatments } \\
\text { can be used; } \\
\text { tolerances for } 3 . \\
\text { and } 4 \text {. tests; } \\
\text { tolerance tables } \\
\text { for } 200 \text { and } 100 \\
\text {-seed tests }\end{array}$ & $\begin{array}{l}\text { MSU; fresh, hard, dead } \\
\text { seed; water retention of } \\
\text { GM; changeover of } \\
\text { alternating T; tolerances for } \\
\text { T; prewashing T limits; } \\
\text { doubtful seedlings }\end{array}$ \\
\hline 2012 & Solanum nigrum & & & $\begin{array}{c}\text { vacuum counters when } \\
\text { seeds are put on the } \\
\text { counting head }\end{array}$ & $\begin{array}{c}\text { method used to classify } \\
\text { fresh seed; } \\
\text { testing extended }\end{array}$ & \\
\hline 2013 & & & $\begin{array}{c}\text { abnormalities: deeply cracked } \\
\text { or broken; split from the tip or } \\
\text { right through }\end{array}$ & $\begin{array}{c}\text { ending a test at a pre- } \\
\text { determined germination } \\
\text { level }\end{array}$ & $\begin{array}{c}\text { ending a test at a pre- } \\
\text { determined germination } \\
\text { level }\end{array}$ & \\
\hline 2014 & & & $\begin{array}{c}\text { point of attachment included } \\
\text { in the } 50 \% \text { rule; } \\
\text { trapped coleoptile }\end{array}$ & $\begin{array}{c}\text { reduction of test period } \\
\text { for Lolium, Festuca, } \\
\text { Poa }\end{array}$ & & $\begin{array}{l}\text { removal of Arachis } \\
\text { seed from the pod }\end{array}$ \\
\hline 2015 & & & categories for seminal roots & $\begin{array}{l}\text { combinations of GM; } \\
\text { particle size of sand; } \\
\text { GM composition }\end{array}$ & & \\
\hline 2016 & & & & $\begin{array}{c}200 \text { seeds for BIC; } \\
\text { omitting the first count } \\
\text { in O; } \\
\text { retesting process }\end{array}$ & $\begin{array}{l}\text { germination when } \\
\text { disinfection is applied }\end{array}$ & counting errors \\
\hline 2017 & Carica papaya & & & & $\begin{array}{c}\text { MSU; } \\
\text { tolerance tables } \\
\text { between laboratories }\end{array}$ & $\begin{array}{l}\text { all dormancy-breaking } \\
\text { procedures can be used }\end{array}$ \\
\hline 2018 & $\begin{array}{l}\text { Brassica } \\
\text { carinata }\end{array}$ & & \begin{tabular}{|c|} 
Glycine max seedlings: when \\
$1^{\circ}$ root is defective
\end{tabular} & $\begin{array}{l}14 \mathrm{~d} \text { instead } 7-10 \mathrm{~d} \text { to } \\
\text { tests in sand or soil }\end{array}$ & & duration of the test \\
\hline
\end{tabular}

MSU - multiple seed units; O - organic growing media; T-temperature; d - days; BIC - Blue International Certificate; BP between paper; TPS - top of paper covered with sand; $1^{\circ}$ - primary; GM - growing media

(Ajayi et al., 2006; Đukanović et al., 2000). For international seed trade it is essential to use uniform criteria for seedling evaluation (Milošević et al., 2007). That's why evaluation of seedlings is explained in detail in the ISTA Rules as well as in the ISTA Handbook on Seedling Evaluation (Don, 2013a) where photos with examples of seedling abnormalities are available to consult. In several occasions list of abnormalities in the Rules has been revised and harmonized with the one in the Handbook
(2008, 2009, 2011). Several researches have shown that abnormal seedlings of corn, sunflower and soybean contribute significantly to the yield (Babić et al., 2015; Craviotto et al., 2001; McDonald, 1994; Prijić et al., 1991). Validation studies were initiated with the aim to reconsider the seedling evaluation criteria. Changes in evaluation of maize and soybean seedlings were introduced into ISTA Rules in 2003 and 2018, respectively. After 10-years investigation it was concluded that maize 
seedlings with coleoptile defects should be considered as normal if the primary leaf is intact or only slightly damaged. Validation study regarding evaluation of soybean seedlings with primary root defects has been finished just recently. New amendment state that such Glycine max seedlings must have at least three secondary roots, each greater than or equal to half the length of the hypocotyls to be considered as normal (ISTA Rules, 2018).

For seedling evaluation of dicotyledons $50 \%$ rule is essential. That's why during revision of the germination chapter in 2011 it was moved as a separate rule. In 2014 clarification of the $50 \%$ Rule was added to include point of attachment (harmonization of ISTA Rules and Handbook, 2009). The $50 \%$ rule does not apply if the two points of attachment of the cotyledons to the seedling axis or the terminal bud itself is necrotic or decayed; such seedlings are abnormal irrespective of the condition of the cotyledons or primary leaves.

In 2011 several more changes in germination evaluation for dicotyledons were introduced. Seedlings with more than 3 cotyledons or primary leaves should be classified as normal seedlings with slight defects. In the same group are seedlings with fused cotyledons. On the other hand, seedlings with cotyledons fused on both sides must be evaluated as abnormal. $50 \%$ Rule is applicable for all dicotyledon species except Phaseolus, where $1 / 4$ of primary leaves is limit for germination evaluation. Also, clarifications regarding damaged seedlings were given. Seedlings should be considered as normal if damage is not affecting the conductive tissue. In 2011, some new abnormalities were also added: seedling unbalanced; detached endosperm in Poaceae and negative phototropism of hypocotyls. In this year, notes for primary root and seminal roots were corrected, as well. In 2013 description of abnormalities were reviewed. New text "deeply cracked" is added to abnormality type "broken seedling” and text "split right through" was added to abnormality type "seedling is split from the tip". In 2014 a very important change was the introduction of "trapped coleoptile" in the list of seedling abnormalities. For seed analysts even more important was the explanation given in the note that seedling with trapped coleoptile is normal if development otherwise is normal. This is a very common type of abnormality for sweet corn and maize hybrids seed with white pericarp. In 2015 new categories were added for seminal roots defects.

\section{IMPROVEMENTS (ADVANCES) IN TESTING PROCESS}

In this paragraph changes that made seed testing easier and faster will be discussed. Basically, those changes were step forward to client's needs.

In this respect, at the beginning of the $21^{\text {st }}$ century it was allowed to take pure seeds for germination either from pure seed fraction or from a representative fraction of the submitted sample (ISTA Rules, 2002). This way organization of seed testing in the laboratory became more flexible. Samples can be placed for germination testing and during this process purity can be evaluated. It is especially important for those species where purity testing is time consuming.

Germination testing for international seed trade (for international certification) is based on testing 400 seeds. Testing less than 400 seeds, but not less than 100, was allowed in 2011 for expensive seed (basic seed, hybrid vegetable seed etc.). Furthermore, if seed is not of high value, ISTA Rules (2016) permit germination tests with 200 seeds, but only for Blue International Certificate.

In order to shorten the time between sample receipt and issuance of required documents, another option was introduced in the ISTA Rules (2013). At the request of the applicant, a germination test can be terminated at a pre-determined germination level. After the completion of validation study by the germination committee, testing period was reduced for certain grasses Lolium 14 to 10; Festuca 21 to 14; Poa 28 to 21 days (ISTA Rules, 2014). Campos and Tillmann (1997) and Tomaz et al. (2010) concluded that it is possible to terminate the germination test for some species with single countings. Caldeira et al. (2015) emphasized that there is the possibility of reducing the evaluation period of the germination test on the seventh day after sowing in sand at the temperature of $25^{\circ} \mathrm{C}$.

Changes related to quality control were also introduced during the period covered in this paper. One of them was concerning checking $\mathrm{pH}$ in a substrate. ISTA Rules prescribe the $\mathrm{pH}$ range $6.0-7.5$. This was obligatory until amendment in 2002 stating that laboratory must provide evidence that $\mathrm{pH}$ value outside this range does not affect the germination results. In 2011 Rules became even more flexible allowing that $\mathrm{pH}$ and conductivity measurements can be replaced by biological tests.

There were several more changes regarding the testing procedure. In 2002 parallel testing was permitted. That means that more than one test method from those prescribed can be applied to a sample at the same time and the best result is reported.

In 2015 combinations of growing media (e.g. filter paper and sand) were allowed provided that each growing media is checked. In the same year, requirements for particle size of sand and organic growing media became less stringent. New rule state that at least $90 \%$ of sand particles must pass through a sieve of 2 $\mathrm{mm}$ width (previously $0.8 \mathrm{~mm}$ ), while for organic growing media it is recommended that $90 \%$ of the particles should pass through a sieve of $3 \mathrm{~mm}$ width (previously $2 \mathrm{~mm}$ ).

In the ISTA Rules (2016) two important amendments were introduced. One of them considers fungicide treatment in the laboratory for species other than Arachis and Beta. Seed treatment is routinely used for seed disinfection of many species (Ivanović et al., 2002; Milošević and Ćirović, 1994; Falloon, 1982). In case untreated seed is exported and fungicide is used for disinfection in the laboratory, parallel tests have to be done with and without treatment and both results must be reported on the ISTA Certificate. A large number of ISTA accredited laboratories $(41 \%)$ are applying fungicide treatment prior to germination testing in the laboratory (Don, 2013b). Second amendment in 2016 was concerning the retesting process. In ISTA Rules (2011) very complex procedure was given for retesting of samples with results out of tolerance. Consequently amendments were made in section on tolerances and tolerance checking to allow third and fourth tests to be carried out using the same method. Flow chart was added to illustrate the retesting procedure. In 2016 different test method was allowed if replicates exceed tolerance, so retesting became easier and more practical.

\section{CALCULATION AND REPORTING RESULTS}

The result of the germination test is expressed as percentages by number of normal and abnormal seedlings and hard, fresh and dead seeds. Sum of those percentages must be 100 . Germination test results are reported in whole numbers, so if a result is found to be zero it must be reported as „0“ not " 0.0 ”. (ISTA Rules, 2002). In the same issue, procedure for rounding results was amended: Percentage of normal seedlings is rounded first, integer parts of the remaining percentages are added. If the sum is not 100 , further steps have to be conducted: value with the greatest decimal part among remaining percentages is rounded to the upper whole number, integer parts of the remaining percentages are added and if the sum is not 100 steps 1-2 are 
repeated. In the case of equal decimal parts, the priority order is: abnormal seedlings - hard seeds — fresh seeds — dead seeds.

In ISTA Rules (2006) clarifications on how to evaluate and report fresh seeds were given. If $5 \%$ and more of fresh seeds are present, their potential for germination must be determined by dissection, tetrazolium test or excised embryo. In the previous issue, $\mathrm{X}$ ray method was also listed, but now deleted, since it is not appropriate for evaluation of fresh seeds. Seeds with the potential to germinate are reported as fresh, while those determined not to have the potential to germinate are reported as dead. Clarification that the method used to classify seed as fresh must be reported on the Certificate was given in the Rules (2012). Contrary to the fresh seed, hard seed are just reported on the Certificate, assuming that they are viable. Research by Milivojević et al. (2003) revealed that small percentage of hard seeds are not viable due to undeveloped or damaged embryos.

Reporting results on the ISTA Certificate must be uniform and has to provide adequate information to the applicant. Rules for reporting results are very precisely defined, and must be strictly followed. For new changes introduced in the Rules, instructions for reporting on the Certificate are always given. Statements for amendments discussed in the previous paragraph are presented in this paragraph. When germination test is ended at a pre-determined germination level, following statement is obligatory: "Upon request of the applicant, the germination test was terminated after ...days. The prescribed test period is ...days.” (ISTA Rules, 2013). When a fungicide pretreatment is used in the laboratory, the name of the chemical, the percentage of active ingredients and the method of treatment must be reported on the ISTA Certificate. Germination test must be reported under 'Other determinations' and followed by: 'This method is not covered by the International Rules for Seed Testing'. Test results for non-treated seeds must be reported under 'Germination' in the spaces provided (ISTA Rules, 2016).

Similar text „The test is not covered by the Rules“, must be written when the pre-treatment for breaking seed dormancy not given in the Rules is used.

Precise details and duration of the dormancy-breaking procedure also must be reported on ISTA Certificate.

Number of tolerance tables in the ISTA Rules was changed in 2011 by addition of tolerance tables for checking of 200 and 100 -seed tests and in 2017 by re-introduction of tolerance tables for comparing results between laboratories.

\section{CLARIFICATIONS}

ISTA Rules are very complex and comprehensive. Sometimes Rules can be wrongly interpreted, that is why clarifications regarding delicate issues are often added.

In 2005 clarification for germination of tree and shrub species was added. For certain species double test is required. It was made clear that both germination test methods (with and without prechilling) are mandatory.

Very important clarification from the practical point of view was given in 2006, regarding checking of tolerances. Rule state that tolerances are to be applied at least on the category of normal seedlings. That means if results of dead seed are out of tolerance, germination doesn't have to be repeated.

During revision in 2011 clarifications were given for definitions of fresh, dead and hard seed; evaluation of seedlings from multiple seed units (one normal seedling is considered sufficient to classify the unit as normal); substrate watering (water retention of growing media should be adjusted for species' needs, based on the maximum WHC); changeover of alternating temperatures (gradual changeover lasting no more than $3 \mathrm{~h}$ ), tolerances for range of temperature (e.g. $5-10{ }^{\circ} \mathrm{C}$ no additional tolerances may be applied $5 \pm 2^{\circ} \mathrm{C}$ and $10 \pm 2^{\circ} \mathrm{C}$ ); prewashing temperature limits $\left(25 \pm 2{ }^{\circ} \mathrm{C}\right)$ and drying $\left(20-25^{\circ} \mathrm{C}\right)$.

In every day evaluations on the first count, analysts are making decisions if seedlings are normal or they should be left till the final count. Rules in 2011 clarified that doubtful seedlings must be left until the final count, unless it is obvious that they will never develop into normal seedlings.

ISTA Rules (2014) explained that seed of Arachis must be removed from the pod before a germination test although the pod is a pure seed unit.

Clarifications on required actions when counting errors occur were given in 2016. When more than 5 seeds are lost or found during germination test of 400 seeds, the test must be repeated. Very important explanation was added in 2017 that all dormancy-breaking procedures can be used, even when no recommendation is listed in Table 5A (methods for germination tests).

\section{CONCLUSIONS}

In the past 18 years numerous changes in germination testing were introduced into the ISTA Rules. Thirteen new species were added, and several test methods were amended. New growing media and combinations of growing media were allowed. New types of abnormalities were added and for some species the criteria for seedling evaluation were changed. Clarifications were given on the testing procedures, calculation and reporting of results. Finally, the most important changes were made in order to make seed germination testing more flexible and faster. It can be concluded that the amendments to the ISTA Rules are necessary in order to harmonize seed testing and modern trends in seed trade.

ACKNOWLEDGMENT: This paper is a result of the research within project TR 31068, "Improvement of maize and soybean traits by molecular and conventional breeding" supported by the Ministry Education, Science and Technological Development, Republic of Serbia.

\section{REFERENCES}

Ajayi, S.A. Rühl, G., Greef J.M. (2006). Impact of Mechanical Damage to Hybrid Maize Seed from Harvesting and Conditioning. Seed Technology. Vol. 28, No. 1, pp. 7-21.

Anonymous (1931). Report of the Sixth International Seed Testing Congress. Proceedings of the International Seed Testing Association, 3, 5-394.

Aranciaga, I. (2010). ISTA validation study on germination testing of Brachiaria brizantha (A.Rich) Stapf. Method Validation Reports for Rules Proposals 2010. Page 2-21.

Association of Official Seed Analysts. 2006. Rules for Testing Seeds. Association of Official Seed Analysts. Section 4.10, Table 3. 35p.

Babić, V., Kravić, N., Babić, M., Popović, A., Ivanović, D. (2015). Viability testing of maize landraces accessions from MRIZP gene bank. Romanian Agricultural Research, 32, 8591.

Baskin, C., Baskin, J. (2014). Seeds: ecology, biogeography, and evolution of dormancy and germination. Second Edition, San Diego: Academic Press.

C.M. Caldeira, M.L. Moreira de Carvalho, J.A. Oliveira, V.Y. Kataoka, A.I. Freire (2015). Reduced time for evaluation of the germination test for sunflower seeds. Journal of Seed Science, v.37, n.1, p.070-075.

Campos, V.C.; Tillmann, M.Â.A. (1997). Avaliação da metodologia do teste de germinação para sementes de tomate. Revista Brasileira de Agrociência, v.3, n.1, p.37-42. http://www.ufpel.tche.br/faem/agrociencia/v3n1/artigo06.pdf 
Copeland, L.O., McDonald, M.B. (2001). Principles of seed science and technology. $4^{\text {th }}$ edn. Norwell, Massachusetts: Kluwer Academic Publishers. 488 pp.

Craviotto, R.M., Salinas, A.R., Yoldian, A.M., Arango, M.R. (2001). Soybean (Glycine max L. Merr.) response to the loss of part of its hypocotyls-radicle axis in the production of secondary and/or adventitious roots. Seed Science and Technology, 29 (2), 471-476.

Don, R. (2013a). ISTA Handbook on Seedling Evaluations, $3^{\text {rd }}$ Edition, International Seed Testing Association, Bassersdorf, Switzerland.

Don, R. (2013b). Responses to Questionnaires on seed treatment, light, sand and organic growing media. $30^{\text {th }}$ ISTA Seed Congress, June 12-18, Antalya, Turkey. www.seedtest.org/upload/cms/user/ISTA-TCOMs-June151130-GER-Ducournau.pdf

Docournau, S., Garreau, P., Léchappé, J. (2010). Use of Organic Growing Media as primary substrate for the germination of Vicia faba L. seeds. Method Validation Reports for Rules Proposals 2010. Page 58-63.

Đukanović, L., Srebrić, M., Milićević, M., Pavlov, M. (2000) Uticaj žetve i dorade na životnu sposobnost semena soje. Selekcija i semenarstvo, Vol. VII, No. 3-4, 33-36.

Falloon, R.E. (1982). Fungicide seed treatment of maize to improve establishment and control seedling pathogens. New Zealand Journal of Experimental Agriculture, 1982, Vol. 10, 197-202.

Fiedler, K.A., Gutormson, T. J. Brix-Davis, K. A. Patin A. L. (2010). Evaluation of Creped Cellulose Paper Covered with Sand as an ISTA Medium for Glycine max, Helianthus annuus, Phaseolus vulgaris and Zea mays Method Validation Reports for Rules Proposals 2010, page 40-45.

Hilhorst, H.W.M., Karssen, C.M. (1989). The role of light and nitrate in seed germination. In: Recent Advances in the Development and Germination of Seeds. Edited by Raymond B. Taylorson. Plenum Press, New York.

International Seed Testing Association (1953). International Rules for Seed Testing. Proceedings of the International Seed Testing Association, Vol. 18, No 1, pp. 1-69, Copenhague V.

International Seed Testing Association. International Rules for Seed Testing, edition 2002-2018. ISTA Basserdorf, CH.

International Seed Testing Association web site. www.seedtest.org

Ivanović, D., Lević, J., Marić, A., Penčić, V. (2002). Bolesti kukuruza i njihovo suzbijanje. U knjizi: Bolesti, štetočine i korovi kukuruza i njihovo suzbijanje. Grupa autora, Izdavači Institut za kukuruz Zemun Polje i DOO “Školska knjiga” Novi Sad.

Jones, S., Allen, E. (2017). Activity report on behalf of the ISTA Rules TCOM. Seed Testing International, No. 154, 20.

Jones, S., Kahlert, B. (2005). ISTA Rules Latest. Seed Testing International, No. 130, 45.

Klitgård, K. (2002). ISTA 1924-1999 Progress Report on the Testing of Germination. ISTA Historical Papers, 2, 35-58.

Kojić, J., Milivojević, M., Stojadinović, J., Marinković, M., Ivanović, D. (2011). The analysis of proficiency test results on the seed purity and the other seed determination for ten-year period, Journal on Processing and Energy in Agriculture, 15 (4), 255-259.

Kojić J., Stevanović, N., Petrović, T., Milivojević, M., Jovanović, S., Tabaković, M. (2016). Ring analyses in the proficiency assessment of authorised seed samplers. Journal on Processing and Energy in Agriculture, 20 (1), 9-12.
McDonald, M.B. (1994). Seed lot potential: viability, vigour and field performance. Seed Science and Technology, 22, 421-425.

Milivojević M. (2016). Kvalitet semena ZP samooplodnih linija kukuruza različitih grupa zrenja i genetičke osnove. Doktorska disertacija, Poljoprivredni fakultet, Novi Sad.

Milivojević M., Stojadinović, J., Kojić, J., Ivanović D., Vujaković, M. (2008). Međulaboratorijska ispitivanja u proveri stručnosti semenskih laboratorija. V Naučno-stručni Simpozijum iz selekcije i semenarstva Društva selekcionera i semenara Srbije, Vrnjačka Banja, 25-28. maj 2008, Zbornik abstrakata str. 82

Milivojević, M., Srdić, J., Branković Radojčić, D., Vukadinović, R., Kojić, J., Petrović, T. (2017). Comparison of two cold test procedures for seed vigour evaluation of maize inbred lines. Journal on Processing and Energy in Agriculture , 21 (2), 115117.

Milivojević, M., Stojadinović, J., Ivanović, D. (2003). Germination and Viability - Parameters of Seed Quality, Journal of Scientific Agricultural Research, Vol. 64, No 227228, 5-12.

Milošević, M., Milivojević, M., Ivanović, D., Vujaković, M. (2007). Towards the standardization in seed testing. Maydica, 52, 335-341.

Milošević, M., Ćirović, M. (1994). Seme. Institut za ratarstvo i povrtarstvo, Novi Sad.

Muschick, M. (2010). The evolution of seed testing. Seed Testing International, No. 139, 3-7.

Popović, R., Milićević, M. (1987): Uticaj dorade semena na povredu perikarpa. Semenarstvo, 9. 37.

Prijić, Lj., Jovanović, M., Popović, R. (1991). Effect of abnormal seedlings on major characters and grain yield in soybean. Seed Science and Technology, 19, 67-71.

Ripka, Z. (2010). Between-paper method for the germination test of Brassica spp. and Sinapis alba. Method Validation Reports for Rules Proposals 2010. Page 46-57.

Ristić, N., Todorović, V., Adžić, S., Zdravković, J. (2013). Promene klijavosti plavog patlidžana (Solanum melongena L.) u periodu skladištenja poreklom iz plodova različite starosti. Selekcija i semenarstvo, 19 (1), 35-42.

Sečanski, M., Mirić, M., Radenović, Č., Marković, K., Jovanović, Ž., Popović, A. (2015). Značaj kontinuiranog unapređenja proizvodnje i kontrole osnovnog semena ZP hibrida kukuruza. Selekcija i semenarstvo, 21, (2), 103-117.

Steiner, A.M., Kruse, M., Leist, N. (2008). ISTA method validation 2007: a historical retrospect. Seed Testing International, No. 136, 32-35.

TeKrony, D.M., Hunter, J.L. (1995). Effect of Seed Maturation and Genotype on Seed Vigor in Maize. Crop Science, 35, 857862.

Tomaz, C.A.; Martins, C.C.; Carvalho, L.R.; Nakagawa, J. (2010). Duração do teste de germinação do capim-tanzânia. Revista Brasileira de Sementes, v.32, n.4 p.080-087. http://www.scielo.br/pdf/rbs/v32n4/09.pdf

Vujaković, M., Balešević-Tubić, S., Jovičić, D., TaškiAjduković K., Petrović, D., Nikolić Z., Kostić, M. (2011). Germination and vigor of soybean seed produced under different agro-meteorogical conditions. Journal on Processing and Energy in Agriculture, 15 (3), 157-159.

Vujinović, J., Milićević, M., Đukanović, L. (2006). Dužina posležetvenog dozrevanja semena strnih žita. Časopis za procesnu tehniku i energetiku u poljoprivredi, Vol. 10, br. 3-4, str. 117-118.

Received: 29. 01. 2018.

Accepted: 21. 03. 2018. 